\title{
1978 年度秋季学術大会記事・発表要旨
}

1978 年度東北地理学会秋季学術大会は秋田市の秋田大 学鉱山学部附属鉱業博物館講堂を会場とし, 秋田地理学会 との共催により，10月14日(十～16日 用ににわたって開催 された。

研究発表は 14,15 の両日にわたり発表件数 29 件（自然 系 12 , 人文系 17 ), 1 発表当り 25 分 (口頭発表 18 分, 質疑 応答 7 分）の持ち時間でなされ，地元秋田県下の高等学校 の教師の方々による研究発表も多く, 秋季学術大会の意義 を十分に果されたとい方る。大会参加者は延べ約 120 名余 り，研究発表に際し座長を勤めていただいた方々は下記の 通りであった。

な拉, 大会初日の 14 日午後 6 時からは秋田市内の秋田第 一ホテルを会場に懇親会が催され, 両地理学会々員各位の 交歓がなされた（参加者 40 名）。

巡検は大会 3 日目（16日）に「大潟村の現状と問題点」 をテーマに行なわれたが，多数の現職高校教師の方々の参 加を得て極めて盛況, 有意義のうちに過された。

（文責：菅原 啓）

\section{記}

研究発表座長名

\begin{tabular}{l|lr|l|lr}
\hline 発表番号 & 座長 氏名 & 発表 番号 & \multicolumn{2}{|c}{ 厘 長 } \\
\hline $1-01 \sim 02$ & 杉浦 & 直 & $2-01 \sim 02$ & 石川 & 勲 \\
$1-03$ & 仙道 & 良次 & $2-03 \sim 04$ & 肥田 & 登 \\
$1-04 \sim 05$ & 中山 & 正民 & $2-05 \sim 06$ & 阿部 & 隆 \\
$1-06$ & 小元久仁夫 & $2-07 \sim 08$ & 板倉 & 勝高 \\
$1-07 \sim 08$ & 池田 & 雅美 & $2-09 \sim 10$ & 横山 & 弘 \\
$1-09 \sim 10$ & 西村 & 嘉助 & $2-11$ & 米地 & 文夫 \\
$1-11 \sim 12$ & 北条 & 寿 & $2-12 \sim 13$ & 瀬川 & 秀良 \\
$1-13$ & 今井 & 敏信 & $2-14 \sim 15$ & 渡辺 & 四郎 \\
$1-14$ & 水野 & 裕 & & & \\
\hline
\end{tabular}

\section{1-01 海面養殖の生産額による地域的検討}

河上税

1976 年のわが国の海面養殖業は, 53,324 の経営体 (海面 漁業総数の $23.7 \%$ ）が， 9.2 万 ha の沿海漁場から 85 万 $\mathrm{t}(8.1 \%) ， 2,933$ 億円 (14.2\%) を生産している。これを 8 海区，47 地区 (拊県・支庁別) について, 生産額を指標之 して検討した結果は次の通りであった。

1）総生産額の順位により最高位地区，高位地区，中高 位地区，中位区および低位地区に 5 区分したところ，太平 洋区，瀬戸内海执よび東シナ海区に，最高位や高位の地区
が多く存在し，海況や海岸地形など養殖漁場の自然条件に 恵まれたところに当っていた。

2）品目別生産額の構成比により混合地区，複合地区， 単一地区执よび超単一地区に 4 区分したところ，古くから の養殖産地は混合地区や複合地区に含まれるものが多く, 新しい養殖産地は単一地区や超単一地区に多く含まれた。 一般的には混合地区から複合地区へ，さらに単一地区への 方向, つまり多品目の養殖から漁場に適し, 商品価値の高 い $1 \cdot 2$ 品目の選択的養殖への傾向がみられた。

3）総生産額の 11 力年の伸びにより最も発展した地区, 著しく発展した地区，中位に発展した地区，やや発展した 地区执よび停滞した地区に 5 区分したところ, 最も発展し た地区や著しく発展した地区には，新品目が導入されたと ころが多く, 漁場の自然条件に恵まれていた。他方, 停滞 した地区は埋立によって漁場が狭められて来た古い産地で あった。

要するに海面養殖は, 自然条件に恵まれた沿海漁場で, 漁民の努力や漁業協同組合の管理，政府や地方自治体の助 成などによって，市場性の強い品目が選択されて進められ て来た。そして新品目が導入され，改良された養殖技術に 即応できたところが著しく発展し，大産地に成長している。

\section{1-02 東北地方における林業地域の再生}

\section{四津隆一}

山林地域では, 重要度の大小に差があるとしても, 従来 から各種の形式により林業が行われてきた。東北地方で, 特に林業地域とみなされある程度評価されてきた地域は， 青森県北部, 秋田県北部の汪か, 小規模ながら津山, 鳴子, 金山, 田川地区があげられる。これらの林業地域では, 当 然用材生産に主力が括かれている。

これらの林業地域以外の山林地域に扑いて, 用材生産 が必ずしも著しくないが, 特用林産物をふくめて, 林業生 産がかなり行われていた。もっとも集約度に执いて若干の 較差は認められる。また森林率が高い林業地域でも, 薪炭 林が多い地域に抢ける林業の後退は衆知の通りである。

そこで著名な林業地域以外でも, 従来多少薪炭生産以上 に集約的に植林を進め，経済林としての林相をそなえてい る林業地域では，さらに林業地域としての機能を向上させ ようとし, 東北地方でも中位程度の林業地域に打ける基盤 整備を進めることにより，林業地域の再生または積極的な 変容がうかがえる。

1976 年以降設定された中核林業振興地域もその一つで あって, 森林率が高い山林地域であっても, 用材用の林木 
が少なく, 人工林率も低い, いわば粗放的な林業地域とみ なされるなかで，比較的その度合が少ない林業地域が選定 されている。これは新全総の一環としての大規模林業圏の よらな広域なものではないし，無論自然休養林のような近 郊的公共的林業地域とも相違するものである。

\section{1-03 鉱山地域の宗教}

斎 藤 実 則

目的 本研究では, 鉱山地域に括ける山神社・山神祭の 実態, 鉱山地域構成者と宗教, 仏教・キリスト教などの進 出状況, 最近の事情と閉山後の山神社の意義などについて 明らかにしようとするものである。

方法 対象鉱山としては秋田県内の新旧鉱山，大中規模 鉱山と, 三菱細倉鉱山・古河足尾鉱山など 20 余の鉱山を選 んだ。

前記諸鉱山について，現地調査を主に，文献・聞き取り 調査など行った。

結 果

1. 宗教・宗教施設は, 人間生活にとって欠くベからざる ものであり，いずれの鉱山地域においてす，開山と同時 に, 鉱山経営者によって, 金山神社が建立されている。

2. 古い山神社は, 鉱山地域の景観シンボルとなっている もの, 樹木に井杂れて, 神秘性を保っているものなどが ある。

それらの建造物之付属施設には, 美術 -工芸的価値の 高いものがみられる。

3. 山神祭の規模は, 鉱山の歴史・経営規模・経営者の姿 勢などにより，その関係圈は従業員通勤圏・購買供給 圏・医療施設利用圏などと凡そ一致する。

4. 大規模鉱山集落が形成されると, 寺や墓地などがみら れるようになり，まれにはキリスト教関係の施設がみら れる。

5. 鉱山地域構成者の中で, 宗教的行事に係り, 信仰に関 心を持つものは，鉱山事業経営者・管理者と採鉱夫など に多い。

6. 近年, 従来の鉱山地域にみられなかった山神社に係る 諸慣行がみられる。

7. 廃山後, 地元に残されるものは, 金山神社と墓地と硑 であるが，山神社が学校とともに旧鉱山地域住民の心の 紏になっていることは, 当然のこととはいえ, 興味深い 現象である。

\section{1-04 岩手県, 磐井川における低位河岸段丘の構造}

豊 島 正 幸

河岸段丘の研究において, 段丘面の対比および復元とい
ら作業があず最初に必要なことであるが，この作業は扱う 段丘が古くなればなるはど困難さを増す。それは古い段丘 汪ど形態が保存されにくいためである。そこで注目したの が，比較的低位にあって，連続性のよい段丘面である。こ の種の段丘面は形態がよく保存されているため, 段丘面の 復元が容易であり, その構造を把握しやすいといら利点を もっている。ここで,「連続性がよく, 形態がよく保存され ている段丘面のうち，最も低位にあるもの」を $\mathrm{P}$ 面と仮称 する。

東北地方の山間地域の河谷には, 上記の $\mathrm{P}$ 面が広域的に 分布している。本報告では，磐井川において，P面を中心 とした低位の段丘の構造を明らかにすることを目的とし た。

調査は露頭観察が主であるが，高速道路が段丘面を横断 するところでは, そのボーリングデータが有効な資料と なった。

結果は次のとおりである。

（1） P面は埋積谷を伴なっておう，その埋積谷底は現河 㦿付近の高さにある。

（2）しかしながら，P面は埋積作用によって生じた Fill top terraceではない。その理由のひとつは，P面下 $5 \sim 10$ $\mathrm{m}$ に, かなりの幅をもった平滑な不整合面が存在すること であり，ふたつめは，埋積作用によって生じた Fill top terrace は, P面より一段高いレベル（P面との比高 5〜20 m）に見いだされることである。これを F 面と仮称する。

（3）結局, 低位の河岸段丘の発達史は, 埋積谷底の形成 $\rightarrow$ 埋積作用 $\rightarrow \mathrm{F}$ 面 (Fill top terrace) の形成 $\rightarrow \mathrm{P}$ 面 (Fillstrath, Strath terrace) の形成 $\rightarrow$ 現河床といらょうに把握 できる。

（4） $\mathrm{P}$ 面の縦断形は現河床のそれより concavity が小 さい形状を示す。

今後の課題として, $\mathrm{P}$ 面の縦断形の特徴を手がかりに, 山間地域の段丘面形成作用の中味を考えていきたい。な和, $\mathrm{F}$ 面構成物中の木片の $\mathrm{C}^{14}$ 年代は測定中である。

\section{1-05 羽越海岸の段丘と地殼変動}

中田高・今泉 俊文

筆者らは, 数年来, 日本海沿岸の地震性地殼変動につい て調査・研究を行なってさたが, 今回は, 羽越海岸に扣い て段丘面の変位から地殼変動を検討し, 他地域との変動之 比較してみた。

本地域の段丘については, 米地（1966）が比較的詳しい 報告を行ない，段丘区分とその形成期について論じた。そ の後, 太田 (1971) は段丘区分の再検討を行ない，段丘面 の変位から地殼変動を言及した。

段丘面の区分・対比について筆者らの調査結果と太田 
（1971）のそれに大差はない。太田が主張するように，羽 越海岸南半部では南端部に隆起の極を持つような変動が第 四紀後半に継続的に進行した。この変動傾向は, 沖積段丘 やベンチの高度分布からは検出し兄ず, 第四紀後半の地款 変動の解釈を困難にしてさた。新潟地震時には, 本海岸線 は沈降傾向にめり, 松田（1967）はこの地域が地震時拉よ びその直後には沈降するが地質学的期間では沈降でない地 域の代表的地域と解した。

筆者らのベンチの高度分布の観察によって, 本海岸地域 が南北二つの地殼変動域に分けられ，それぞれの変動域の 広がりが, 約南北 $30 \mathrm{~km}$ にわたることが推定された。また, 段丘面の変位も南部海岸の変動は, 南半部の変動域内に招 さまって怙り，段丘の傾動率も第 3 段丘（太田の $\mathrm{M}_{1}$ ) で $2.7 \times 10^{-3}$, 第 4 段丘（太田の $\mathrm{M}_{2}$ ) で $2.0 \times 10^{-3}$ であった。 のような変動傾向は山地の高度分布に調和的であり, 西津 軽・男鹿半島飞拈ける地殼変動と相通ずるところがある。 西津軽・男鹿半島地域は地震隆起の傾向之段丘面の高度分 布の傾向が調和的である。また, 羽越海岸も含めて, 東北 地方の日本海沿岸の隆起地域が藤田至則（1970）のいら島 弧変動のブロックの縁辺地域にあたり, これらの地域が, 似たよらな変動様式をとると推定されることから, 本地域 の地款変動についても, 新潟地震時の変動をもって性格ら゙ けを行ならこと汇なな叔検討の余地があるとい方る。

\section{1-06 仙台市茂庭付近の地形}

$$
\text { 寺戸恒夫 }
$$

丘陵の浸食過程を考察して, 仙台市西部の茂庭住宅団地 付近の地形を，大規模マスムーブメントにより形成された ものと推定したので，それを検証するためと調査を行なっ た。梨野背後の急斜地は, 全体として円弧状の平面形を示 し，現在でも局部的に小崩壞を起して拈り，かつての滑落 崖と考学て不自然ではない。ただし，北西部では開析が著 しく進んでいるので, 崩壊（地すべりを含む）の発生は古 い。梨野付近の小丘列女るいは低地列は崩積地を推定させ る。東方の佐保山林道付近では方向が異なるので, 全体の 動きは単一とは考光られない。域内の地質は，半沢湾か (1953), Shibata (1962), 新妻 (1967, 修論) の記載があ る。下部の旗立層は三者之も共通するが, 上部層は綱木層・ 湯元凝灰岩部層・梨野凝灰岩層之異なる。この原因は, 上 部層が浮石質凝灰岩・凝灰岩塊・安山岩塊あるい訬岩・ 磁岩よりなり，全体として乱れた地質構造を有することに 起因すると考觉る。10 数個の山地群は, 石灰岩起源・断層 起源之は岩質・分布より考克られない。桑代（1961）のい らシラスドリーネとも形態的に異なる。茂庭の凝灰岩層の クラックは, 表層風化による節理に沿うもので, 最も顕著 な例は高田断層通過地とされる山脚突端部にあり, 地下水
による浸食の可能性は少なく，むしろ斜面の物質移動と関 連すると考光る。凹地と円頂丘が接して存在する点より， 急斜した円頂丘の山腹が崩壊して，かつての小谷の下部を 埋めて形成したと解釈される。域内には, 中規模の崩壊は 数例認められる。しかし，山地の中にはこれで説明できず， 透水性の大なる地質を考慮しないと解決できないものがあ る。以上の諸点より, 決定的な証拠はないが, 地形・地質 の総合判断より, 茂庭の特異な地形は, 大規模マスムーブ メントにその後の中規模マスムーブメントが加わって形成 されたものと考光る。

\section{1-07 猪苗代湖北地方の農村家屋形態}

一一門造民家の分布之変容を中心に一

$$
\text { 杉浦直 }
$$

目的 東北地方に扮活る農村家屋形態の地理学的研究の 一環として, 猪苗代湖北岸平野一帯を取り上げ, 農村家屋 形態の地域的特色，特に中門造民家を中心とする家屋タイ プの分布，とその近年の変貌を考察・把握する。

調查 対象地域に括汁る農村家屋形態を概観するため に, 猪苗代町役場税務課家屋台帳及び家屋平面図を使用, 27 集落を選択し 675 戸の農家形態を分析した。現地調査 は，学生実習等により 9 集落行っているが，ここでは大在 家，新在家，西真行，上称次，下称次の 5 集落の資料を重 点的に使用した。

タイプ設定 対象地域の家屋形態を把握するため, 次の ような便宜的な家屋タイプの分類を行った。すなわち，A : 中門造民家，B：ドマニワ部側前面が拡大している直家, $\mathrm{C}$ ：直家，さらに $\mathrm{B}, \mathrm{C}$ についてはドマニワ部の広い古いタ イプ $\left(\mathrm{B}_{0}, \mathrm{C}_{0}\right)$, ドマニワ部が汪とんど無くなった新しいタ イプ $\left(\mathrm{B}_{n}, \mathrm{C}_{n}\right)$ を区別した。

結果 昭和 30 年代に扮汁る家屋タイプの分布を見ると, いずれの集落に打いても汪とんぞが古いタイプ $\left(\mathrm{A}, \mathrm{B}_{0}\right.$ ， $\mathrm{C}_{0}$ ）で占められている。特に中門造民家（A）飞注目する と, 平野西半に多く長瀬川以東の地域では少なくなってい る傾向が見られる。現在（昭和 52 年）の分布を見ると, 過 半が新しいタイプの家屋 $\left(\mathrm{B}_{n}, \mathrm{C}_{n}\right)$ になって拈り,ここ 15 年ぐらいの間に，急激な家屋形態の変化が生じたことがわ かる。

30 年代前半之現在とを，役場資料に上る 675 戸の平均に よって数值的に比較すると, 母屋面積では 47.00 坪 $\rightarrow 51.21$ 坪とあまり大きな变化はない。しかし建物総面積に占める 付属舎の割合を見ると, $39.96 \% \rightarrow 48.73 \%$ と増加しており， 付属舎面積そのものも $58.6 \%$ の増加を示している。

個々の家屋の変化を, さらに具体的に見ると, 多くの家 屋に扮いて，母屋内の居住空間の拡大・近代化々，作業・ 收納空間の縮小が見られ，その分付属舎における作業・収 
納空間が拡大している。こうした家屋機能の分化過程にお いて，中門造民家を始めとする伝統的家屋は，その姿を消 していったのである。

\section{1-08 位置選定の始源的要因}

山田安彦

時代と地域の如何を問わず，位置の選定は生活と生産に 重要な課題である。位置選定要因を概観すると, すず気候・ 地形・地質などの自然的要因，つぎに自然的諸条件を基礎 とした生産性や交通の有利性などの経済的要因, それに加 えて領域内統轄上の政治行政的要因，また周辺隣接する地 域之の政治的位置関係要因，あるい攻勢上・守勢上の軍 事的要因や自然災害に対する防災的要因などが考兄られ る。しかし，実際上の位置の選定にはそれらの要因が複合 している場合が多い。各部門から複合的・総合的に位置選 定要因を配慮してもな扔災禍に襲われ凶既が発生している 場合が少なくないので，国家鎮護泰平安穏や地域住民の安 泰息災を祈願するために, 古代人は彼等が信じた自然的秩 序の摂理・条理に沿らように斉整主義を尊重して地上に建 設物（記念物・施設・集落など）を象徵的に配置した。こ の象徵が媒体となって人間と自然（神）が接近するものと 古代人は信じていた。かかる心像的観念や信仰的信念に よっても位置を選定している場合が少なくないのではない かと考えるのである。要するに知覚的知識による位置選定 要因を追及したいと考省ている。

遠古を辿れば，理想的な位置要因は信仰と結合して，四 神相応といら公式になでなっている。しかしそれだけでな く, 冬至・夏至の太陽出没方位を見通しらる位置を選定要 因に想定したのではないからうと推論しうる。その試論の 場之して常陸国府や平泉，それに藤原京之鏡作坐天照御魂 神社と三論山の関係，および平城京などがある。その推論 を無視しえない。何故なら，後漢書や旧唐書によると，都 城の南か南東に郊祀円丘を設けて祭天の義を執行してい る。しかし，わが国の場合，桓武朝までその徵証はないが， 長岡・平安両京にはそれがあったといわ机ている。

\section{1-09 飯豊山地山稜付近の斜面における物質移動}

桧 垣 大 助

飯豊山地の主山稜部には, 西緩東急の非対称山稜が発達 している。現在の山稜付近に扣ける地形形成環境の評価と, 非対称山稜の形成を考える 1 つ資料として, 簡単な地形 実験を行なった結果を報告する。

実験地は，山稜付近で比較的物質移動の大きい事が予想 される残雪砂レキ地を 2 力所 (鳥帽子岳, カイラギ沢上部)
と強風砂レキ地 1 力所（飯豊本山）である。

（1）残雪砂レキ地の実験結果

各実験地に，直線状のペンキラインの設置，地中への八 リガネ等の埋設を行ない, 前者は1976-78 年, 後者は1976 -77 年の変形を調べた。その結果, 1976-77 年, 斜面物質の 移動は微かであったのに対し，1977-78 年にはかなりの移 動が発生した。その営力としては, 主に融雪期や消雪後の 降雨による earth flow, wash, gully 侵蝕などが考えられ る。そして, 径の小さいレキ程移動距離が大きく, $30 \mathrm{~cm}$ を 越えるようなレキは，汪とんど移動していない。また，地 衣や草本の着生している所の移動は小さいか又はほとんど ない。

（2）強風砂レキ地の実験結果

ここでは，地中に埋設したハリガネ数本について 1 年間 の変形を調べただけで，資料は少ないが，1977年秋から78 年春にかけては，移動量は小さいようであるが垂直的広が りを持った物質移動一扣そらく frost creep一が認め られ，1978年春から夏にかけては，末とまった降雨による 細粒物の表面流出が主体となっているよらである。ここで も径の小さいレキは，汇とんど移動していない。

現在, 飯豊山地主山稜部では, 冬季の多雪・強風, 夏季 にも降水量が多いという気候条件に対応して, 季節的に異 なる営力で物質移動が行なわれているとみなされる。また, 移動状態から, 現在の環境下で, 非対称山稜の発達は, 注 とんぞ進んでいないと思われる。

\section{1-10＼cjkstart霧ケ峰高原での岩塊の流動観測とその速度}

$$
\text { 松 本 繁 樹 }
$$

blockstreamに打沙る岩塊の流動・集積機構や流動速 度, 形成環境などの問題を解明する 1 つの手がかりは，い わゆる「生さている地形」を探し出し，そこで一定期間継 続観測や野外実験を行ってみることにあると思われる。こ らいった観点から発表者は, 霧ケ峰高原に点在する安山岩 岩塊をとりあげ，昭和 48 年 8 月以来，その流動についての 継続観測を実施中である。今回の発表は,この観測につい ての昭和 53 年 5 月現在なでのいわば中間報告であるが, そ れらを要約すると以下のようになる。

(1) 車山 (1,925 m) 山頂の南北両斜面では, かなりの数 の岩塊が現在明らかに流動していて，それらの年平均流動 速度は核 20〜6 mmであり，その最大值は 4.6 年間で $117 \mathrm{~mm}$ である。もっとも北斜面では, 大岩塊ではっきりと 動いているものは 1 つかないが，最大径 $0.5 \mathrm{~m}$ 以下の小 岩塊になると, 51 年 8 月以降の観測分も含めて, そのほと んど全部がかなりの速度での流動を示しつつある。な扤 51 年 8 月に観測を開始した車山山頂西斜面とスキー場斜面と については，未だ詔差の範囲を越えたものがないので，流 
動の有無についての判定は, 今後の観測結果にまたねばな らない。

(2) いっぽらゴマンオ高原では, 誤差の範囲を越えたの

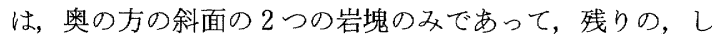
かもその多くはごくわずかな差しか示していない。した がって現在までの観测では，それらは汪とんどないし全く 動いていないもののように見える。

（3）霧ケ峰高原で現在流動中の岩塊について，その移動 量を冬半年と夏半年とに分けて比較してみると, 多くの岩 塊では, 凍結・融解交代日数の多い冬半年の方に大きな值 が表われている。このことは, ここでの流動が, いわゆる ソリフラクションないしは rock creep の形で行なわれて いるとする想定に矛盾しないが，ただこの点についての詳 しい検討は，今後の観測結果ををたねばならない。

\section{1-11横手盆地における養豚業の現状}

\section{石川 雄造・伊藤尚}

横手盆地の総合研究の一環として，この地域の畜産をと りあげ，その中でも全県的に飼着頭数の多い豚，いわゆる 養豚業をとりあ汭てみた。

今回は, 特にこの地域の中でも最も典型的な水田地帯で ある旧里見村 (現在, 平鹿町・雄物川町の二町にわたる) における養豚業の現状に焦点をあててみた。それによると

○飼養戸数の変化をみると, 県のそれよりもはるかに緩 慢な減少がみられ，ここ 2,3 年は変動がなく安定した 状態を示し, すべてが複合経営の農家湌豚が中心であ る。

（飼養頭数は著しく伸び, 構造改善, 生産性の向上, 減 反政策等により昭和 45 年ごろから農業近代化資金の 借入等によって水田に大型豚舎を建て, 多頭化をはか り, 後継者養豚の推進が行なわれ, 現在に至っている (そのため出稼者は少なくなった)。しかし華やかに見 光る大型養豚もその多くは借物経営で, 小作経営に等 しい。

○飼料は医とんぞ購入飼料で，費用は大部分農協からの 借金によっている。(「エサ小作」的性格)

(2)労働力は特別困難な面はみられず, 田植光, 稲刈りが 若干遅れる程度でさしつかえない。

そのためか農業機械の導入率が高い。しかし，規模拡大 とともに大きな問題が生じた。それは畜産公害（ふ九尿処 理問題)である。現在はなんとか水田への還元と余ったも のは話合いで他地区の果樹園, 畑作農家から利用しても らってどうにか処理している。しかしこれ以上はもう容易 でなくなってきているのが現状で，その解決策と発展策と して，山地養豚をといら案が具体化してきている。

\section{1-12＼cjkstart東北地方におけるぶどう栽培地域の変化}

石川雄 造

目的 東北地方に拈けるぶどうの栽培面積は, りんごの 減少傾向とは対象的に増加傾向にある。このことは, 昭和 36 年に制定された果樹農業振與特別措置法によることも あったが, 昭和 46 年から始まった稲作転換による影響が強 かった。東北地方で古くから栽培されていたのは山形県だ けで, 他の県はあまり栽培面積も多くはなかった。しかし， 最近は青森, 岩手, 福島県でる新植計画により既存園の周 辺ばかりでなく，新興地にぶどらを新植する傾向がみられ るよらになってきた。かかる現状から, ぶどら栽培の地域 的拡大, 栽培技術の変化, 流通過程などについて考察し, ぶどうの栽培地域の変化を明らかにしたい。

万法 栽培面積の推移をみるため, 東北農政局と各県お よび市町村の資料を利用した。また $1965, ' 75$ 年の農業セ ンサス, 昭和 51 年果樹基本統計調查も使用した。

成果 栽培面積の増加の著しいのは山形で, 次いで青森, 岩手, 福島, 秋田県と続くが, 宮城だけは減少傾向を示し ている。昭和 40 年と 52 年との比較でみると, 山形の場合, 村山地方は $55.1 \%$ から $58.0 \%$ ，青森の津軽地方では $45.8 \%$ から $52.3 \%$, 馬㴊川流域の三八地方は $27.9 \%$ から $33.2 \%$, 岩手の北部地方は $10 \%$ から $16.2 \%$, 北上川上・中 流域は $15.0 \%$ から $33.7 \%$, 秋田では内陸盆地から砂丘地へ と集中化がみられる。次に栽培農家の一戸当り面積は 25 〜35aで, 大部分は複合経営である。

栽培地の地形状況をみると, 東北地方では, 平坦地に $58.0 \%$, 傾斜地に $37.6 \%$ となっているが, 山形では平坦地 $50.9 \%$, 傾斜地 $43.8 \%$, 青森では平坦地が $82.3 \%$ となってい る。栽培品種をみると山形ではデラウェアが $80 \%$ 以上なの に, 他の県はキャンベルが多い。出荷先之出荷割合では, 農協へ $45 \%$ 以上出荷しているのは山形, 岩手, 福島, 秋田, 直販の多いのが宮城, 青森である。

1-13秋田湾地域における農業の变化 一天王町の事例一

斎藤実則・菊地勝俊 - 小野一已

目的 本研究では, 秋田湾地域の農業の変化を昭和 40 年 から 50 年までを明らかにする。

対象地域 秋田湾地域の中間的位置にある南秋田郡天王 町を選んだ。

方法 秋田県・天王町の各種統計資料, 文献を使用した。 その他現地調査・聴き取りによった。

結 果

天王町は人口の流入に伴い, 専業農家の減少と畑地・原 
野の宅地化が著しく, 砂丘上の畑作の卓越地帯で畑地の改 廃が進んでいる。

羽立 水田単作地帯の羽立では, 八郎潟地先干拓によっ て経営耕地の拡大があり, 機械化の進行之出稼ぎ者の激增 をみせた。近年，転作田がみられるようになった。

大崎 果樹栽培地区の大崎では, 稲作と果樹との複合形 態がとられ，市場性の低い梨からぶどうへの転換がみられ る。出荷は共販体制がとられるが, 一部には個人販売も行 われている。

江川 天王町唯一の漁港をもつ江川は, 農家の半数が半 農半漁である。近年, 漁業が衰退傾向にあり, 土地生産性 の低い農地の宅地造成がみられる。

上出戸 砂丘地での露地栽培が行われるが，一部ではビ ニールハウス，ガラス温室を利用した蔬菜・花さの園芸農 業が盛んになってきた。

追分西 秋田市に隣近する追分西では, 畑地の改廃が目 立ち, 工場用地・公共施設用地・一般住宅化が著しい。

\section{1-14 宮城県沖地震による仙台周辺の被害と地形} 中田高

1978 年 6 月に発生した宮城県沖地震 $(M=7.4)$ は震源か ら約 $100 \mathrm{~km}$ 離れた仙台市周辺で様々な被害をひき起した が，被害の分布と地形（人工改変地形を含む）に興味ある 対応が認められた。

沖積低地では被害の大小は沖積層の厚さと関係があると いわれているが，今回の地震では，地表付近の地盤条件を 反映した微地形と強い相関が認められた。すなわち，現海 岸線沿いの浜是では家屋や墓地に汪とんど被害がなく，基 盤上にある旧仙台市街地の被害と大きな差がなかった。

これに対し, 自然堤防や内陸側の浜堤, 後背低地内の埋立 地に大きな被害が発生した。海岸線沿いの浜堤では，地表 下約 $20 \mathrm{~m}$ まで $\mathrm{N}$ 值 30 に及ぶ砂層が分布するが, 他の微高 地では表層を構成する数 $\mathrm{m}$ 以下の砂層下に $\mathrm{N}$ 值 0 に近い軟 弱な泥炭層・粘土層が分布し，地盤条件を著しく悪くして いる。名取川右岸の砂磁質の扇状地性三角州の地域では被 害は中間的であった。家屋被害は屋根が重く柱・壁の少な い古い家屋に集中したが，きわめて地盤条件の悪い新興住 宅地では新しい家屋も被害をさけることはできなかった。 墓石の軽倒から推定した水平加速度も被害と対応した大き さを示し, 旧仙台市街や海よりの浜堤は $250 \mathrm{gal} て ゙$ 震度 $\mathrm{V}$ であったが，自然堤防や後背湿地では $400 \mathrm{gal}$ 以上で震度 VII に達するところがあった。

一方，丘陵地を開発した新興団地にも大きな被害が発生 した。仙台市緑ケ丘のよらに急傾斜の開析谷の埋土部に発 生した地盤破壊のような被害のほか, 北部の南光台や鶴ケ 谷団地のような大規模な団地では被害は切土部之埋土部の
境界に集中した。これは軟弱な埋土部でのゆれが大きく， 不等沈下や境界部の性質のちがいからゆれを受けたためと 考えられる。同様な地形改変がなされた八木山団地では, 被害は北部丘陵に比較して著しく小さかった。このちがい は，埋土部の摇れの大きさの差がきいていると思われ，こ の原因として埋土量と埋土部の含水量のちがいが考えられ る。これには改変前の地形, とくに谷底の形状と傾斜に関 係があり, 北部丘陵の開析谷が谷底の広い傾斜のゆるい(1 度以下）ものであったのに対し，八木山では，緩傾斜の谷 底でも 3 度以上であり，谷は狭く枝わかれも少ない。造成 後の宅地も前者は平坦化された部分が多いが，後者は傾斜 があり，表流水の水はけも良く，埋土部の地盤条件に大き な差となったといえる。

\section{2-01 冬季の低気圧通過時における降水域の変化 一中部地方の場合一}

田坂 郁夫

低気圧に伴なら降水は北西季節風とともに冬季の主要な 原因の 1 つであり，季節風による降水が汪とんどみられな い太平洋側地域においては特に重要である。78年日本地理 学会春季大会に拈いては, 気象官署のデータを使い冬季の 低気圧通過時に打ける降水分布の全国的な特徵を報告した が，今回は区内観測所の資料も加え検討を行なった。ただ し，本発表では分布の地域的な違いをマクロに検討した結 果を報告し, 地形条件との関係などの考察は今後の課題と して捈く。

地域には中部地方をとりあげ，調査期間は 1970 年〜 75 年の冬季 $12,1,2$ 月, 計 18 力月とした。用いた資料は日界 を9時とする区内観測所の日量である。

低気圧に伴なら降水量の変化は地域的差違に富み，いく つかの特徵ある型が認められる。太平洋側地域においては, 南岸低気圧の通過時にだ降水量の増減する型が一般的て ある。すなわち, 降水は南岸低気圧の接近, 通過に伴ない 増減し, 日本海低気圧による降水はほとんどない。この型 は太平洋の沿岸部葟ぞ顕著であるが, 内陸部でも同様に認 められる。一方, 日本海側地域では低気圧の通過中に少な く, 通過後に増加する型が認められる。しかし, 能登半島 や北陸の海岸地域に招いては, 日本海低気王の通過中に降 水の増加する型がみられる。

南岸低気圧通過時に降水は西より始まり, 低気圧が九州 南方を通過する頃には当地方全域に及ぶ。この時, 降水量 は太平洋岸に多くなり, 内陸部や日本海側では少ない。低 気圧の通過後は日本海側の特に山地部に扣いて降水が増加 し, 太平洋側では降水はみられなくなる。これに対し, 日 本海低気王通過時の降水は, 日本海側地域に限られること が多いが, 多降水の地域は, 通過前: 山地部, 通過中: 海 岸, 半島部, 通過後：山地部之推移する。 


\section{2-02 日本および韓国の気候変動にみられる帯状性につ いて}

$$
\text { 境田清 隆 }
$$

発表者は以前，わが国の 8 月気温の年々変動には，東西 に類似，南北に異質といら構造があることを報告したが， 今回はこれに韓国のデータを加兄，当地域の気温変動にみ られる帯状性について検討した。また日照時間，降水量に ついても同様の検討を行なった。

方法としては，まず地点間の相関係数の分布から変動構 造の概略を把握し，次に各地点のデータに 5 年の荷重移動 平均を行なって 5 10 年の変動を, また 10 年の算術移動平 均を用いて長期傾向を明らかにした。その際，汇湆 $140^{\circ} \mathrm{E}$ に沿って旭川から八丈島まで, $130^{\circ} \mathrm{E}$ に沿って江陵から名 瀬まで 2 本の基線を設定し，それぞれについて南北の差違 を明らかにしながら，東西の比較を行なった。

その結果, 8 月の気温と日照時間の変動については, きわ めて䫓著な帯状性が認められた。相関のよい帯状の地域は ENE-WSW に走り，その傾きは経度 $10^{\circ}$ に対し緯度で 3〜4であり，韓国はわが国の東北地方々類似した変動を 示している。また降水量の変動汇関する带状性はきわめて そしいが，長期傾向の観点からみると，韓国と北日本との 間に帯状性が認められた。

5 年の荷重移動平均曲線から, 気温と日照時間の変動に は， $7 \sim 8$ 年周期と 11 年周期が卓越することがわかった。 7 $\sim 8$ 年周期は北半球全体の高温期にあたる 1921 50 年に は本州中央から韓国にかけて広くみられたが，1951 年以 降，不連続的に南日本まで移動している。すた 11 年周期は 太陽の黒点周期に一致しているが，1951 年以降，両者の関 係に乱れが生じている。

なお，周期の顕在化する地域が，どのようなメカニズム でその位置を変兄るのか， 7,8 年周期が何に起因するのか など，今後に残された課題である。

\section{2-03屋敷林からみた宮城県北部の風}

$$
\begin{array}{r}
\text { 設楽 寛・牧田 肇・吉川 厚 } \\
\text { 斎藤曜一・吉永秀一郎 }
\end{array}
$$

観測点のない地域の風の状況の推定には，ふつう偏形樹 と屋敷林が使用される。しかし，偏形樹がことに有効なの は山岳地であって, 平野部では屋敷林の方が普遍的にみら れる。ここで問題になるのは, 屋敷林による風向の特定の 困難さである。ふつら屋敷林は敷地の一方だけを招扔わず， 2 方あるいは 3 方を招打らからである。この上うな場合の 卓越風向を特定する方法が得られれば，屋敷林は平野の風 に関する局地気候研究のために有効となるであるう。 今回調査した宮城県北部には各所に大きな屋敷林が見ら
れる。構造はスギを主体とし，スギの下枝と地面とのあい だに出来た吵間にはササ・ヒノキなどを生えて風の侵入を はばむなど，さまざまの工夫がこらされている。

しかし，平面形は幅の同じ帯状ではなく，一部が他にく らべ特厚くなっている。その最も厚い方向が卓越風の方 向であることはささとり調査でもたしかめられたのでここ れを目やすに調査を行なった。ききとりをふくむくわしい 調查のあいだに，車空からの観察もしたので，かなり広い 範囲を短時間に見ることが出来た。

その結果作成された風向分布図からは，局地的な風向の ずれや収束域・発散域の存在がよみとれ，それらはこれま でなされた風関する研究の結果とも一致するところが多 かッた。

一方，さきにのべた上木の下板と地面の間をふさぐ低木 を欠く屋敷林を見出したが，この形のものは従来しられて いる多雪域に分布していた。屋敷林の下が雪にうずまるた めにその部分からの風の侵入は考充なくてよいからであろ らが，屋敷林の形態が雪々関係することは新たな知見であ る。

\section{2-04＼cjkstart冬季の日本海上における雲分布について} 設 楽

寛

季節風が卓越している冬期の日本海上では，大陸の沖合 いで雲の発生を見，海上を雲域と大陸海岸沿の晴域とに分 ける。その分布は日によって異なるが，本報告では，晴域， いいか光れば，雲域の出現頻度分布を卓越風向每に求めた あのである。

資料は, ESSA-9 の衛生写真, 1969 年 12 月, 1970 年 1 月 抢よび 2 月の 3 力月間約 90 日で, 低気圧の接近している日 と前線のさしかかっている日を除き，雲分布のパターンよ り季節風が典型的に吹走していると判断される例として約 50 日を対象とした。資料処理は, 経・緯線 15 分ごとの交点 ごとに，雲域あるいは晴域に含まれる度数を調べ，卓越風 向は，その写真から海上に発生したすじ雲によって判断し た。

海域によって風向が変るので，広域を対象とすると風系 パターンの類似例が少くなるので, 海域を沿海州, 朝鮮半 島北部，中部，南部の 4 つに分け，それぞれについて卓越 風向ごとに晴域（雲域）の出現頻度分布を求めた。

風向ごとに，特徵的な分布パターンが得られ，それぞれ 雲を発生させ易い海域と晴域が拡がる海域とがある。それ らの軸を大陸側に延長してみると，地形との対応があり， 各風向ごとの結果を重ね合せることによって，海上の雲発 生に及ぼす風上大陸側の地形条件を推定することができ る。

巨視的に見て最大の特徵は，朝鮮半島北部の高海拔山塊 
の風下海域の雲分布であって, 特定の風向に対して雲発生 域が極めて高率であり，他の風向に対しては晴域を拡げる。 前者は日本海上飞発生する収束線と関係しているよう亿考 壳られる。なお, 水温分布との関係については他日を期し たい。

\section{2-05秋田市周辺地域における若年労働力の流出動向} 斎藤 実則・佐藤 文義

目的・方法 本研究では，秋田市とその周辺地域に括け る新規高校卒業者の流出の動態を明らかにすることが目標 である。

資料は 1955 年以降の各高等学校の同空会名簿, 職業安定 所と秋田市周辺における大規模企業の諸資料を使用した。 結果

1. 市内各高等学校の就職率は進学率の向上によって逓 減している。又, 県外就職率も 1972 年以降は減少傾向 にある。工業高校の県外就職率は $39.4 \%$ （1977 年）で あり，実業高校の中では最も高い。

2. 県外への流出動向; 地域別業種別就職者をみると,

(1) 関東地方が全体の $75.8 \%$ を占め, 化学・電気・通 信・機械工業の順となっている。

（2）東北地方は全体の $12.3 \%$ で（秋田県を除く）紙・ パルプ・鉱業などがこの順に多い業種である。

（3）その他では中部の $7.5 \%$, 北海道の $9.1 \%$ などがあ り，機械工業以外はみるべきものはなく，公務員， 建設業などが多い。

3. Uターン; 秋田県への人口逆流（Uターン）は関東 地区が多い。つまり, Uターンは, 他県間の移動量に 比例的である。秋田県へUターン後の就業業種は, 公 務員，商業などが多く，製造業は $15.1 \%$ と少ない。

4. 県内就職; 県内への就業者数の多い地区は秋田市之 その周辺市町村に多く分布し, 県全体の $83.9 \%$ を占 め, 高率である。つまり, 大規模な企業の立地のみら れる地域に集中している。

従って，人口流出の抑制には大企業の誘致が少なからず 影響を及汭していることが明らかである。

\section{2-06 職業別通勤圈について}

$$
\text { 大友篤 }
$$

特定の都市の通勤圈を定める方法には，種々のものがあ るが，多くの場合，圏域の限界を示寸指標值は，かなり主 観的に定められる。これを客観的に定める方法として, 通 勤移動の選択指数（preference index）を用いることについ ては,すでに, 東北地理 26 巻 3 号（1974 年）に执いて報告
した。

すなわち，通勤圈を通勤移動の選択指数（特定都市への 送出選択指数)が 100 以上の地域として定める方法である。 つ委り, 選択指数が 100 以上であるということは, 特定都 市への送出通勤者数が，その市町村の人口に比例した期待 值以上であることを示している。

今回は, この選択指数を, 職業別に適用して, 職業別の 通勤圈の差異を検出した。職業としては，職業大分類のな かから「事務従事者」(ホワイト・カラー）、「販売従事者」 (グレイ・カラー), 「技能士, 生産工程作業者, 単純労働 者」(ブルー・カラー)の 3 階層をとり, 対象都市としては, 東京都区部执よび宇都宮市を選んだ。検出の方法は，次の とおりである。

選択指数 (y)が, 対象都市から当諸市町村までの距離 $(\mathrm{x})$ に直線的に比例して低下寸るものと仮定し，その相関係数 を各職業ごとに算出するとともに，関係式 $\mathrm{y}=\mathrm{b}-\mathrm{ax}$ のパ ラメーターを求め, $\mathrm{g}=100$ の場合の $\mathrm{x}$ を, 対象都市の通勤 圈の限界地点として算出した。

その結果, 3 つの職業階層のなかでは, ブルー・カラーの 通勤圈が, 東京・宇都宮のいずれに执いても, 最も小さく, これに対して, 東京については, ホワイト・カラー, 宇都 宮についてはグレイ・カラーの通勤圈が, それぞれ最も広 いことが明らかとなった。なお, 東京の通勤圈の限界地点 は $52.5 \mathrm{~km}$, 宇都宮のそれは, $33.8 \mathrm{~km}$ である。

\section{2-07 秋田市における中心地区の分化と発展}

\section{白山 雅彦・益子 清孝}

都市が果たす役割の分担，あるいは，都市として成り立 つための諸活動の内部分担が内部地域の機能的分化といら 形をとる。城下町の機能を背景として発展してきた秋田市 は近年著しい市街地の拡大と都市構造の変化が顕著であ る。本報告は秋田市の都市構造, 特に諸機能の地域的分担 のメカニズムを明らかにすることを目的とした。

方法として, 人口の推移々都市化の動向, 事業所の立地 とその特色, 路線地価からみた都市的土地利用, 中心地機 能の分布々その特色，等によって考察した。

資料として, 秋田市の統計, 市街地地図, 秋田市史, 秋 田市総合都市計画, 秋田県事業所名鑑, 国税宁路線地価, 51 年版職業別電話簿他を使用した。

秋田市の中心地区に括沙機能分化は, 昭和 32 年以降, 総合都市計画に因るところが大きい。その構造は公官庁・ 金融・報道機関等の集積にともなら CBD の形成をみた山 王地区と歓楽街としての機能を中心とした大町・南通・中 通地区の二つの核を中心同心円状の配列がみられる。 $\mathrm{CBD}$, 歓楽街の中間及び周辺には旧城下町の奇町 (理旭北 地区）を軸に漸移帯を求めるところができる。さらに，市 
街地周辺に新興住宅区, 西部秋田運河沿いの工業区の展開 をみることができる。

歓楽街は, 広小路中心商店街を基盤とする商業区・中通 地区・川反领食街・有楽町映画館街の社交娛楽機能の卓越 する大町・南通地区，千秋公園・美術館・図書館などの公 共施設の風致地区・千秋地区に地域分化している。城下町 の機能を背景とした秋田市の都市構造は, 秋田駅・駅前バ スターミナルと山王地区を中心とした都市構造に変化し,

大町地区など旧城下町の機能を背景として発展した地区の 機能の純化が顕著となってきている。

このような秋田市の中心地区の分化, 発展は, 都市計画 に則るところが大きく, 一方では, 都市内域交通と遠隔地 交通の結節点への発展の方向が動いた結果と考兄られる。

\section{2-08 仙台市中心部における都心的機能の分布とその变 化}

西原純

本発表の目的は, $\mathrm{CBD}$ の形成過程に和ける $\mathrm{CBD}$ の水平 的拡大の有無を明らかにすることで, これは将来の都市像 を描く上で非常に重要である。従来の研究では, CBD 境界 設定の困難さから，量的議論はなされていなかった。発表 者は, $\mathrm{CBD}$ を構成する機能の分布の広がりと広がりの変化 を標準距離で表現し，CBD の骨格の拡大・不拡大を量的に 論じる。

研究対象地域は仙台市中心部にあたる, 東西 $2.4 \mathrm{~km}$, 南北 $2.6 \mathrm{~km}$ の矩形の地域である。この地域に括沙る銀行・ 保険業・製造業 (鉄鋼・金属・化学・石油) ・ 商社・建設業 ・官公宁の各業種ごとに, 事業所（製造業・商社・建設業 は東証一部・二部上場会社)の分布図を作成した。分布図の 各事業所の東西座標, 南北座標を読みとり, 各業種ごと に東西, 南北座標の平均値を求め, それを事業所の分布の 平均中心点の座標とした。その平均中心点から各事業所ま での距離 $\left(\mathrm{d}_{i c}\right)$ から, 標準距離 $=\sqrt{\frac{\sum_{i=1}^{n}(\mathrm{dic})^{2}}{\mathrm{n}}}$ が求められる。

標準距離の動向から次の結論を得た。銀行・保険業はそ の標準距離が最も短く, 強い求心的集塊の分布パターンを なし，CBD の核を形成している。標準距離はとれぞれ，昭 和 30 年; $230 \mathrm{~m}, 335 \mathrm{~m}, 40$ 年; $305 \mathrm{~m}, 355 \mathrm{~m}, 50$ 年; 320 $\mathrm{m}, 405 \mathrm{~m}$ と, 時代とともに拡大し, CBD の核が拡大してい ることを示している。

製造業・商社の標準距離はそれぞれ, 昭和 30 年; $475 \mathrm{~m}$, $575 \mathrm{~m}, 40$ 年; $375 \mathrm{~m}, 535 \mathrm{~m}, 50$ 年; $400 \mathrm{~m}, 510 \mathrm{~m}$ と, 一定 もしくは縮小している。建設業・官公庁の標準距離は最も 大きく,CBD の外帯を構成している。標準距離はそれぞれ， 昭和 30 年; $780 \mathrm{~m}, 840 \mathrm{~m}, 40$ 年; $785 \mathrm{~m}, 795 \mathrm{~m}, 50$ 年; $750 \mathrm{~m}, 730 \mathrm{~m}$ と, 時代とともに縮小し, 建設業・官公广の
分布パターンは集塊化の傾向にある。そして, $\mathrm{CBD}$ の外帯 を構成する商社・建設業・官公庁の標準距離の動向からみ た CBD の骨組みは抁大していない。

\section{2-09都心周辺部における土地利用の経年変動 一仙台の場合一}

鴨 川武文

昨秋の日本地理学会において, 仙台の東部地区を事例に 事業所の立地および移動の調査を実施し発表したが，その 結果この地区に立地している多くの事業所が都心および都 心周辺部から移動してきていることが明らかてなった。そ こで今回，こうした事業所の移動をもたらす都心，都心周 辺部がどのような特性をるっているか, 特に土地利用の立 場から検討した。使用した資料は昭和 40 年, 52 年の仙台市 建物用途別現況図であり，この図は土地利用の状況を一見 して理解できるといら利点を有している。研究方法は街路 で区切られる239のブロックについて，まずその面積を計 測し, 次に建物 1 個 1 個の面積を計測した。建物について は業務施設, 商業施設, 住宅施設に分類し, それぞれのブ ロック内での諸施設の構成比を算出し困化した。

結果は次の通りである。

業務施設は昭和 40 年では国分町通りに $50 \%$ 以上の割合 で集中立地していた。また，青葉通りも高い割合となって いる。昭和 40 年と比較した昭和 52 年の特色は, 市役所北 部地区での業務施設の新現立地である。この地区は近年貸 ビルの建設が著しく，その結果高い割合になったものと思 われる。

商業施設は昭和 40 年, 昭和 52 年とも東一番丁, 中央通 り, 稲荷小路に集中する傾向は同じであるが, 昭和 52 年で は市役所北側地区での商業施設の新現立地がみられまた， 立町地区でも同様の傾向がある。業務施設, 商業施設は都 心部に対して北部，西北部の方向へ拡大していることが明 らかになった。

住宅施設は昭和 40 年, 昭和 52 年を比較してみると, 都 心部では概してその割合を減少させている。また，市役所 の西北地区では業務, 商業各施設もそれ汪ど増加せず, し かも住宅の割合が相対的に低下した地区があるが，これら の地区では，建物がこわされ，現在では駐車場やあき地と なっており，今後の土地利用がまたれているものと推則で きる。

住宅施設では立町地区に相対的に高い比率となってい る。

最後に都心部は拡大しているが，拡大していないのかと いら議論があるが，都心の景観構成要素を仮りに建物の高 度化とすれば，仙台市全域で建物の高度化は進展している わのの, 密集度でい壳ば市役所北側地区では著しく都心的 景観が市北部でもみられることが判明した。 
2-10 土地利用からみた C.B.D.の二, 三の特性

\section{桑 島勝 雄}

C.B.D. に関しては, 都市研究の一つの焦点として,アメ リカのマーフィー氏らをはじめとして,わが国に执いても, 多くの先学諸氏によって研究され, その内部構造・地域的 特性なぞが，明らかにされている。そして，そこから導き 出された見解や結論は，かなり普遍性の高いものと評価さ れている。

ところで, 従来の研究の多くは, C.B.D.の成熟度の高い 巨大都市・大都市，あるいは数個の類似都市を対象とした もので，いわばC.B.D.の横の研究である。

したがって，C.B.D. 関する研究を深化し，上り普遍性 の高い概念を作りあげていくためには，マーフィーが指摘 するように，さらに，規模・性格の異なる多種・多様な都 市を対象とした，つ毛り横にとどまらず糖の研究が望まれ ている。

筆者は，このような段階にある C.B.D. 研究において，一 資料を提供する意味で，都市規模・性格を異にする五都市 （仙台・福島・盛岡・石巻・古川）を選定し，それらの C.B.D.の土地利用状況の比較から，それぞれの都市にみら れる地域的特性を考察する。

調查方法としては，2,500 分の 1 の市街図に $5 \mathrm{~mm}$ つま り $(12.5 \mathrm{~m})^{2}$ のメッシュを当て, 1 方格, 1 用途を構成単位 として, 各都市の C.B.D.の土地利用図を作成した。資料は, 住宅地図, 電話帳, 路線価格一覽, 都市計画図などである。

また，各都市の C.B.D.の土地利用状況を検討するに当 たって，(1）平面的土地利用面積の広狭，(2) 機能地域の 同化の程度とその地域的広がりの度合，(3) C.B.D.の中心 (core) からの距離と機能地区排列との関係，などの観点 を設定して, 各都市 C.B.D.の土地利用形態のいわば形式的 側面を分析した。

\section{2-11 ニュージーランド南島カンタベリ地方の土地利用 について}

$$
\text { 今 井敏 信 }
$$

ニュージーランド南島のカンタベリ地方はこの国最大の 平野部を有し，農業では牧羊と混合農業が主となっている。 この地方の農家数は国全体の約 $13 \%$ にすぎないが, 羊は同 じく約 35\%(約 950 万頭) 飼育され，小麦・大麦およびオー ト麦は全国生産のそれぞれ $1 / 3 \cdot 1 / 2$ を占めている。

筆者は，この地方を対象として資料收集・現地調查を行 ない, 経営規模・草地の状況・羊拉よび牛とその密度・生 産物などを考慮して，その土地利用を三地帯に大別した。 またそれぞれの地域の農業経営がぞのような土地条件に対 応しているかについても，立地論的立場から，吟味した。
（1）租放的牧羊地帯 南アルプス山地に接する低山性山 地のきびしい気候条件下でみられる牧羊地帯である。経営 規模は 4,000 40,000 ha と大規模であるが，草の成育条件 が悪く, 粗放的経営が行なわれている。しかし良質の羊毛 を産する。

（2）中間的牧羊・牧牛地带 山地部に接寸る丘陵地にみ られる。経営規模は 400 4,000 ha で，その範囲は狭い。

（3）集約的農業地带 平野部に集約的農業がみられ，経 営規模は 400 ha 以下であって比較的小規模である。羊と換 金作物・酪農・園芸と豚や鷂の飼育など多様な営農形態が みられる。扇央部などに打ける草地・作物栽培には灌溉と 土壤条件が重要な意味をもっている。

\section{2-12 八幡平の雪蝕地形}

斎 藤一雄

1. 目的と対象場所 標高 $1,541 \mathrm{~m}$ の国設藤七スキー場 は八幡平頂上駐車場に隣接寸る。行政上松尾村, 林政面で 岩手営林署管轄下にある。ここは藤七沢右斜面即ち東向斜 面で, 対象場所は斜面上部の南北 $800 \mathrm{~m}$ 東西 $100 \mathrm{~m}$ 位。こ この雪蝕地形調査概要を報告する。

2. 資料 昭和 46 年青森営林局活山調查説明書 - 航空 写真・ 1972 年日本自然保護協会第 42 号十和田八幡平国立 公園後生掛地区地熱発電計画汇伴 万学術調查報告書 - 5000 分の 1 地形図。方法としては現地調査及び聞き込みによる。

3. 地形形成の概略 構造谷藤七沢に温泉作用が働い た。斜面は積雪・雪庇により現状を呈する。

4. 気候 活山調查説明書は, 大陸的で寒暑の差が甚し い。降水量は局部的に最も多いと説明する。樹形汇より偏 西風に支配されることがわかる。気温は日本自然保護協会 第 42 号報告書によると, 松尾 $(880 \mathrm{~m})$ で年平均 $5.9^{\circ} \mathrm{C}$ だか らここ $(1.541 \mathrm{~m})$ は年平均 $1.9^{\circ} \mathrm{C}$ と推計する。 5 月 1 日雪庇 の延長およそ $20 \mathrm{~m}$, 積雪深 $10 \mathrm{~m}$ を超すと推定。 8 月中旬に は完全消失する。

5. 地形 約 $800 \mathrm{~m}$ 微傾斜の稜線に頭部を接して, 6 個 の䆶地が斜面に並んである。北から 1 3 番目の寉地は人工 的に全半潰状態。スライドは第 4 窪地を主対象とした。各 窪地は各円頂丘・後背斜面・緩斜面・床濕地池塘がある。 各窪地にはまた若い经地が数個ある。大観して, 階段状を 呈し, 植被の中に地盤露頭が数多く見られる。

6. 結論 積雪状態・地形から「雪による浸蝕」と考光, また宔地が相互に浸蝕し合っているので「雪蝕䆶地の複合 地形」であると判断した。 


\section{2-13 飯豊山地御西岳付近の雪涳}

山中英二

飯豊山地は東北地方で最もょく雪窪の発達している地域 のひとつである。演者は御西岳南斜面にある典型的な形態 を有する雪淮群の調査を行ない, 調査地域の雪窪の特徵(形 態・地表状態・残雪分布・植生・土壤等）を明らかにする とともに，雪窪を形成する営力について調べた。

雪窪は 2 個の大きな圈谷状地形の圈谷壁を削り込んで形 成されていて, 直径は $100 \sim 200 \mathrm{~m}$ ある。雪寉は浅い圈谷状

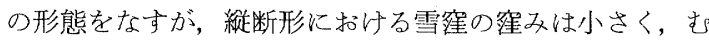
しろ直線的なものさ光ある。調査地域では残雪の消失時期 と対応した植物群落の同心円状の配列が明瞭に認められ る。8月末以降まで残雪が残る雪窪中央部は広い残雪砂砅 地をなすが，砂砂は概して薄く，ところどころには基盤が 露出する。砂碟の下には風化の著しく進んだ花崗岩の基盤 がある。

1977 年 10 月に残雪砂磼地の磥にペンキの点をつけて測 線 7 本を設け，そのうち 4 本を翌 1978 年 9 月に改測した。 それに上ると各実験地の表面礫の平均的移動量は 0.5 2.7

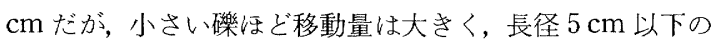
砅では平均移動量 $1.3 \sim 7.8 \mathrm{~cm}$ であった。地表状態等から 判断すると, 移動は主として融雪水や雨水のリル・ウォッ シュ的な営力によるものと考光られる。ソリフラクション が起こっていることを示唆する測線の花綵状の変形やフロ フト・クリープによると思わ机る礫の移動はなかった。る た，雪田に割れ目が形成されて支持力を失った残雪が书行 し，そ扎に伴って礫の下方への移動や基盤岩の破碎・削剝 が行なわれている。

しかし，雪窪中央部の砂砂下に風化した基盤があること から，現在雪窪内で働いている削剝はそれ汪ど強くないと 考光られる。また，植生の侵入によって地表面が安定にな り現在は化石化している雪窪, あるいは下方からのびてき たガリーによって破壊されつつある雪窪が飯豊山地に数多 くみられ, 活発なニベーションの作用によって雪窪が形成 されたのは過去のある時期だと考穴られる。

\section{2-14秋田県における定期市の变貌}

仙道良次

現在, 秋田県内の定期市は 42 力所で開設されている。明 治 25 年現在では 22 力所, 昭和 10 年現在では 24 力所, 昭 和 41 年には 39 力所と増設されてきた。これは新潟県の 58 力所次次ぐ全国でも稀有の存在といえる。

しかし，現実には近代化されつつ专る流通経済のもとで， 形態的にも, 体質的にも, また, 数量的にも大きく変化し てきており，全国的には衰退もしくは廃止の方向にある実
情である。

秋田県内の定期市では, 日本経済が高度成長の時流飞 乗った昭和 41 年から, 景気後退した 10 年後の昭和 $51 \cdot 52$ 年だけでも大いに変貌してきたが，この間スーパーマー ケットをはじめとする常設店舗の近代化による定期市への 影響や交通機関の発達, とりわけ自動車交通の普及によっ て，道路交通規制が政しさを増し，とくに国道・県道路上 の使用不可となり, その交通量の少ない裏小路や個人の所 有地利用，また，河川敷・公用地の空地などを代替光地と するなど，顧客の集散に不便な位置に移動を余儀なくされ ている。

なお，定期市で販売される生鮮食料品は，食品衛生上， 保健所の行政管理が厳重で, 従来の上らな安易な販壳が大 巾に規制されている。それに最近は市場専用トイレや駐車 場の設置問題招よび水道料・電気料の増大，開設後の清掃

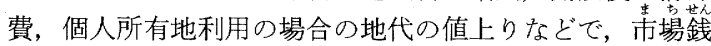
が高交り, 市場維持費が累積して運営上幾多の問題が現出 している。このような諸問題は, 出店数の減少を誘発し， とくに新鮮な野菜商である農産物生産者の露天商（近隣農 家の主婦）が輧減して, 従来の簡易組立式木造小屋掛から 鉄骨造りに切換えられるなど，その変貌を確認できる。

しかし，定期市多設県の本県には，市日，市場専業商人 の組織強化, 商店率や産業構造之の関係, 市場堤力度など 存続の可能性を温存させている。

\section{2-15 東北地方の第 2 - 第 3 次産業の地理学的研究} 宮 崎 禮次郎

本研究は, 日本地理学会 1975 年度春季学術大会, 314 「東 北地方の就業人口からみた産業構造の変化」を発展させた ものである。

日本経済の発展を, 国民純生産額の成長率をもって, 昭 和 30 年を 100 とし, その変動を地域的にみると, 第 1 位は 近畿地方 (指数 1017.28) 一昭和 46 年一。次か関東 870.32 , 第 3 位は中部 767.82, 最も低かったのは, 九州の 557.33 で あり，東北は 582.42 で九州に次いで低かった。都道府県別 では, 第 1 位千葉県 (1192.64) 第 2 位埼玉県 (1082.29), 第 3 位神奈川であり，人口集積も著しかった。

経済の成長率は, 第 1 次産業より, 第 $2 \cdot 3$ 次産業飞打い てた学ず高く, 経済の発展するその過程で, 第 1 次産業就 業人口は, 減少し, 第 $2 \cdot 3$ 次産業は増加する。経済成長率 の高い地域程, この第 1 次産業人口減少, 第 2 次・3 次産業 人口の增加傾向（労働の産業間移動）は，上り顕著に現れ ることは, 経験的に知られた事実である。第 $2 \cdot 3$ 次産業人 口の第 1 次産業人口に対する比をもって, 産業構造近代化 俰数とし，この值の大小の程度でその地域産業近代化の度 合いを計量的にあらわそうとした。 
昭和 30 年・ 35 年・ 40 年・ 45 年・ 50 年の国勢調査資料 を用い, 東北の各市町村毎の近代化係数を各統計年度每に 算出し, 各市町村の昭和 30 年の値を 100.0 とし, 各年度の 指数を算出し，近代化の経年変化を観察した。

昭和 50 年の近代化係数をみると, 福島県では, 福島市・ いわき市・郡山市・白河市・合津若松市，宮城県では，仙 台市・石巻市, 山形では, 山形市・米沢市, 岩手県では, 盛岡市・釜石市，秋田県は秋田市のみ，青森県では，青森 市・八戸市がいずれも， 5.01 以上の高い值を示している。 概して, 福島・宮城・青森の各県で値の高い市町村が多い。 また第 2 次産業より，第 3 次産業が高いことを示してい
る。特に青森県は 2 次産業に対して 3 次産業が高い。

昭和 50 年の全国平均近代化係数に対する同年の各市町 村の関係数の比で，全国の傾向と比較すると，全国より高 い値を示したのは, 青森県は, 青森市・十和田市・平館村・ 今別町・三廐村・柏村・田舎館村など 12 市町村, 岩手県 は, 滰沢村・都南村など 12 力市町村, 宮城県は, 最高の泉 市はじめ 24 力市町村。秋田県は, 井川村・天王町・峰浜村 など 8 市町村。山形県は, 西川町はじめ 9 力市町村。福島 県は，大信村・楢葉町はじめ 14 力市町村。

合計 79 力市町村で, 東北全市町村 408 のらちの $19.4 \%$ が全国平均値以上で女った。

\section{8 年秋季学術大会巡検報告}

大会 3 日目, 午前 8 時 30 分秋田県民会館前出発, 参加者 50 名。バスにて秋田藩時代の内町 (侍町) 広小路通りから 旭川を渡り，外町（町人町）山王大通りを県庁前から臨海 工業地带に拔计, 途中都市計画湾よる行政庁舎・報道機関 の移転集中に伴う都市化・計画的工業地帯形成の実態を見 ながら土崎港（秋田港）にいたる。飯島製錬所・東北電力 をみながら, 出戸浜, 天王, 船越を経て, 9 時 40 分頃化, 秋 田県昭和農業改良普及所大潟支所（旧大潟村入植訓練所） に到着。ここで秋田県農試場大潟支所原種生産科長佐々木 力氏之昭和農業改良普及所大潟支所の柴田義彦氏から,「大 潟村の営農上の諸問題」と題して次のような講話があった。 1. 県農試大潟支所の主な業務は, 低温重粘土水田に沏计る 大型機械利用と土壤生産力増強実験, 田畑複合機械化営農 技術実験, 一ド口土壤栽培素材調查, 水稲原種, 小麦原々 種生産実験であること，2．大型機械に上る標準的作業行 程には, 水稲乾田直播栽培, 水榉機械移植, 秋播小麦, 大 豆などがあること，3.10アール当りの労働時間は, 水稲 が 28.4 時間 (秋田県, 76.4 時間, 全国 79.7 時間), 秋播小 麦が 3.96 時間（全国 23.4 時間），大豆が 29.4 時間（秋田 県 84.3 時間, 全国 26.3 時間) であり, 日本のモデル農村 を目指した労働時間の短縮が行われていること，4. 田畑 複合経営として畑作では小麦・大豆・小豆・アムスメロン の栽培が行われていること, 5.51 年度の 1 農家当りの粗 収入は 1400 万円, 経費 700 万円, 生活費 350 万円を差引い た 350 万円がレジャ一費に使用されている。6. 10 a 当り 收量, 水稲 $600 \mathrm{~kg}$, 小麦 $250 \mathrm{~kg}$, 大豆 $200 \mathrm{~kg}$, 小豆 $150 \mathrm{~kg}$, などである。討議を通した営農上の諸問題として, a. へド 口土壌のため排水対策が最大の問題で, 個人経営化してい る営農であっても, 大規模暗渠事業は共同で行わざるを得 ないこと, また土壤の乾燥次第で田畑複合経営が可能にな ること, b. 数年間の水稲連作のため, 土壤条件は悪化しつ つあり, 今後 13 年周期の輪作体系の導入が必要なこと, c.
全国各地からの入植者のため主婦を含めた村民のコミニ ケーションが不足しがちなこと, が指摘された。次に大潟 村公民館で, 村長の宮田正渞氏から「大潟村の推移之問題 点」と題して次のような講演があった。

1. 潟の開発計画は 120 年前の安政年間に始委り,渡部斧 松の「八郎潟䟱水案」は実現出来ず，明治・大正・昭和の 各時代に立案されたが, 国営事業としては, 昭和 27 年 7 月, 秋田市に農林省八郎潟干拓調査事務所の設置, 昭和 29 年, オランダのヤンセン教授・フォルカー教授の来日, 装年 $\mathrm{FAO}$ 調查団の来日, 昭和 35 年 5 月, 秋田市に八郎潟干拓 事務所設置, 着工, 昭和 40 年 8 月八郎潟新農村建設事業団 設置, 昭和 39 年 10 月 1 日大潟村誕生, 2 . 昭和 42 年, 第 1 次入植開始 (56 戸), 昭和 43 年 2 次入植 (86 戸), 昭和 44 年 3 次入植 (175 戸), 昭和 45 年 4 次入植 (143戸), その 後, 国の生産調整により入植が中断したが, 昭和 49 年 5 次 入植 $(120$ 戸) を含め, 現在入植農家数 580 戸である。入植 者は, 1 都道 36 県に拈よぶが, 現在 1 戸当り 15 ha である こと, 3. 入植者の営農は, 標準的には 6 戸 90 ha を単位と し, トラクター, 大型コンバイン等の農業機械を共同利用 し, 合理的経営を行ない収穫物の処理は, 農産物乾燥調整 貯蔵施設を基本とした田畑複合を行なっている。水稲作は 直播栽培を終極の目標としているが, 土㙵条件が悪いので, 機械移植が主体。4. 新農村は他産業と比較しての所得格 差の是正, 専業機械化一貫体制, 生産と生活の場の分離, 完全協業モデル農村を志向したが，減反をよぎなくされ， 農民の動摇は否定出来ない。農民の願いは，新村建設の原 点にかえることであると……

この後, カントリーエレベーター・北緯 40 度・東経 140 度交合点と稲刈現場を視察し, 午後 4 時 30 分, 秋田駅前に 帰り解散した。

(案内者 宮崎禮次郎・肥田 登・飯塚喜市・石川雄 造・益子清孝) 